\title{
ДО ЮВІЛЕЮ ВІДОМОГО БІОХІМІКА, ПЕДАГОГА ТА НАУКОВЦЯ МИХАЙЛА МИХАЙЛОВИЧА КОРДИ
}

13 лютого виповнилось 50 років ректору ДВНЗ «Тернопільський державний медичний університет імені І. Я. Горбачевського МОЗ України» Михайлу Михайловичу Корді, доктору медичних наук, професору, відомому біохіміку, педагогу, вмілому організатору та дипломату.

Михайло Михайлович пройшов шлях від студента, аспіранта, асистента, доцента, професора, завідувача кафедри, декана до ректора Тернопільського державного медичного університету, який очолив з лютого 2015 року.

Народився професор М. М. Корда у селі Верин Миколаївського району Львівської області. У 1982 році закінчив школу з золотою медаллю. З 1982 до 1988 року навчався у Тернопільському державному медичному інституті, який закінчив із відзнакою. У цьому ж році вступив до аспірантури при кафедрі біохімії. у 1991 році захистив кандидатську дисертацію на тему «Антиоксидний статус організму при гострому токсичному ураженні печінки і його корекція ентеросорбцією і антиоксидантами». В подальшому наукові дослідження проводив у напрямку вивчення механізмів захисту організму від хімічних уражень, тому після того, як став асистентом кафедри біохімії, вдало поєднував викладання з роботою над докторською дисертацією на тему «Порушення окислювальних процесів і захисних систем організму за гострого хімічного ураження печінки та шляхи їх корекції», яку успішно захистив у 1998 році в Одеському державному медичному університеті.

Незважаючи на молодість, він отримав звання професора, та це не зупинило його науковий порив. Михайло Михайлович продовжував займатись науковими дослідженнями у вивченні оксигеназних і вільнорадикальних реакцій у біологічних системах, їх пошкодження при дії високотоксичних хімічних сполук за умов антиоксидантної недостатності, обґрунтування пероксидної теорії хімічного ураження гепатоцитів та його корекцію.

У цей період М. М. Корда досконало вивчив англійську мову та оволодів комп'ютерною на- укою. Це дало йому можливість стажуватися, брати участь у наукових конференціях у зарубіжних країнах (Австрії, Латвії, Німеччині, Іспанії, Японії). 3 лютого 2003 до березня 2004 року Михайло Михайлович перебував у закордонному відрядженні за програмою обміну (The Exchange Vizitor Program), метою якого була науково-дослідницька робота на кафедрі хімії і біохімії Університету Огайо (США).

Під час перебування у США Михайла Михайловича зацікавили дослідження, пов'язані 3 утворенням оксиду азоту (NO) в гепатоцитах, а також клонування гена і ступінь експресії генів NO-синтази. В цьому ж університеті він читав лекції з біохімії та токсикології, проводив практичні заняття зі студентами.

Після повернення в Україну продовжував працювати на посаді завідувача кафедри медичної біохімії Тернопільського державного медичного університету імені І. Я. Горбачевського. Через рік М. М. Корда на пропозицію того університету США взяв участь у конкурсі на заміщення посади «запрошеного професора» кафедри хімії і біохімії. Він успішно пройшов конкурс і виконав усі вимоги до претендентів, що дозволило заключити контракт на трирічний термін роботи. Загалом чотири роки наполегливої праці в університеті за океаном стали важливою віхою творчого зростання вченого, відкрили нову плідну сторінку в його науково-педагогічній діяльності. Цей безцінний досвід Михайло Михайлович використав у подальшій роботі в рідному університеті.

В Україні професор М. М. Корда започаткував новий перспективний науковий напрямок - вивчення біохімічних механізмів токсичності наночастинок різної природи в біологічних системах.

Михайло Михайлович вдало поєднує наукову, викладацьку й адміністративну роботу.

Протягом семи років як декан факультету іноземних студентів з метою популяризації університету та залучення до співпраці нових партнерів М. М. Корда перебував у багатьох закордонних відрядженнях, збільшив чисельність

ISSN 2312-0967. Фармацевтичний часопис. 2015. № 1 
іноземних студентів у кілька разів, за його безпосередньою ініціативою університет неодноразово відвідували офіційні особи посольств і консульств ряду країн.

Як завідувач кафедри медичної біохімії М. М. Корда створив разом із педагогічним колективом потужну методичну та інформаційнотехнологічну базу для студентів і викладачів, у тому числі для англомовних студентів. За його ініціативою і безпосередньою участю створено базу віртуальних навчальних і контролюючих програм з біохімії для більшості практичних занять, які зареєстровано як авторські свідоцтва. Михайло Михайлович Корда - заступник головного редактора наукового журналу «Медична та клінічна хімія», член редколегії журналу «Медична освіта», науковий консультант журналу «Фармацевтичний часопис», відповідальний редактор нового медичного журналу «International Journal of Medicine and Medical Research». Під його керівництвом відбуваються всеукраїнські та міжнародні конференції, присвячені питанням теоретичної та практичної біохімії.

За період своєї наукової діяльності М. М. Корда $€$ автором понад 250 наукових і навчальнометодичних публікацій в Україні й за кордоном, у тому числі 10 патентів на винаходи, 2 навчальних посібників. Він підготував 1 доктора і 4-х кан- дидатів наук, під його керівництвом ще 6 здобувачів успішно виконують дисертації.

На посаді завідувача кафедри і декана факультету іноземних студентів професор М. М. Корда докладав багато зусиль та енергії для організації та вдосконалення навчально-методичної роботи кафедри та факультету.

Професор М. М. Корда був першим науковим консультантом видавництва «Укрмедкнига», він вклав свої знання, зусилля, творчу енергію у розвиток видавничої справи в університеті.

За багаторічну сумлінну працю, високий професіоналізм професор М. М. Корда неодноразово був нагороджений почесними грамотами, дипломами Кабінету Міністрів України, Міністерства охорони здоров'я, подяками Тернопільської обласної державної адміністрації, міського голови м. Тернополя за організацію благодійної діяльності іноземних студентів.

Професор М. М. Корда - талановитий педагог, порядна, доброзичлива та чесна людна, яка $€$ справжньою гордістю сучасної науки.

Редакційна рада та редколегія журналу «Фармацевтичний часопис», друзі та колеги, наукова спільнота від щирого серця вітають Михайла Михайловича з ювілеєм і бажають міцного здоров'я, родинного щастя, добробуту, благополуччя, життєвого оптимізму та творчої наснаги!

ISSN 2312-0967. Pharmaceutical review. 2015. № 1 